\title{
Changes in shrub fecundity in fourwing saltbush browsed by cattle
}

\author{
ANDRÉS F. CIBILS, DAVID M. SWIFT, AND RICHARD H. HART
}

Authors are Research Specialist, School of Renewable Natural Resources, The University of Arizona, Tucson, Ariz.85721, email: acibils@Ag.arizona.edu (on leave from INTA-EEA Santa Cruz and Universidad Nacional de la Patagonia Austral, Río Gallegos, Argentina); Associate Professor, Rangeland Ecosystem Science Department, and senior Scientist, Natural Resource Ecology Laboratory, Colorado State University, Fort Collins, Colo. 80523; and rangeland scientist, USDA-ARS High Plains Grasslands Research Station, Cheyenne, Wyo. 82009. At the time of the research, the senior author was PhD candidate, Rangeland Ecosystem Science Department and Natural Resource Ecology Laboratory, Colorado State University, Fort Collins, Colo.

\section{Abstract}

Shrub fecundity is critical to long term persistence of fourwing saltbush (Atriplex canescens (Pursh) Nutt.) populations at our research site on the shortgrass steppe in Colorado. We conducted a 2-year experiment to test hypotheses concerning the impact of cattle-browsing on fecundity-related variables in fourwing saltbush. Protection from cattle browsing was significantly associated with floral phenotype shifts toward femaleness, occurring mostly in monecious shrubs $(1 \%$ and $13 \%$ of grazed and protected shrubs, respectively). Sex shifts observed at the individual shrub level did not translate into detectable alterations of sex ratios at the pasture level. Shrubs exhibiting no flowers were considerably more abundant in browsed pastures $(26.5 \%)$ than in exclosures $(1.5 \%)$. Nonflowering occurred as frequently in female $(3.6 \%)$ as it did in male $(\mathbf{1 . 8 \%})$ phenotypes. Percent utricle fill was not related to previous year's cattle browsing regime (39\% and $44 \%$ in protected and grazed shrubs, respectively) but rather to crown volume of the fruiting female and to the gender of and distance to the nearest neighboring shrub. The influence of cattle-browsing on reproductive output of fourwing saltbush occurred mainly through its inhibition of flowering.

Key Words: Atriplex canescens, sex change, nonflowering, utricle fill, cattle browsing

Herbivores can affect plant fecundity (sensu Richards [1997]) in a number of ways. In most cases they reduce or suppress flowering and fruiting, yet they can also stimulate it by promoting compensatory fruiting responses (Paige and Whitham 1987 , Hendrix 1988, Lowenberg 1994, Crawley 1997). Fourwing saltbush (Atriplex canescens (Pursh) Nutt.) populations at our research site on the shortgrass steppe in Colorado appear to persist mainly through sexual reproduction, therefore, factors that reduce shrub fecundity can have significant effects on the long term persistence of this critical forage resource.

Research was funded by the Agricultural Research Service of the United States Department of Agriculture, High Plains Grasslands Research Station, Cheyenne, Wyo. The Instituto Nacional de Tecnologia Agropecuaria (Argentina) provided personal support for A. Cibils. Authors wish to express their thankfulness to Durant McArthur, Dave Steingraeber, Bill Lauenroth and 3 anonymous reviewers who provided helpful comments on earlier versions of this manuscript, and to Mary Ashby, Jeff Thomas, Stan Clapp, Dale Hill and Mike McArtor who provided valuable help in the field.

Manuscript accepted 27 Apr. 02

\section{Resumen}

La subsistencia de poblaciones de Atriplex canescens (Pursh) Nutt. en nuestro sitio de estudio en la estepa de pastos cortos de Colorado depende en gran medida de los índices de fecundidad de los individuos que las componen. Se condujo un experimento de 2 años de duración para poner a prueba hipótesis relacionadas con el impacto del ramoneo bovino sobre variables asociadas a la fecundidad de arbustos de $\boldsymbol{A}$. canescens. La exclusión del ramoneo bovino estuvo significativamente asociada a cambios de fenotipo floral de arbustos masculinos o monoicos que produjeron flores femeninas $(13 \%$ y $1 \%$ en clausuras y potreros pastoreados, respectivamente). Los cambios en el fenotipo sexual observados a nivel de individuos no se tradujeron en alteraciones detectables en las proporciones fenotíoicas de sexos a nivel de potreros. La ausencia de floración se observó en mayores proporciones en arbustos ramoneados $(26,5 \%)$ que en arbustos en clausuras $(1,5 \%)$. Dicho fenómeno ocurrió en frecuencias similares en fenotipos femeninos $(3,6 \%)$ y masculinos $(1,8 \%)$. EI porcentaje de frutos llenos en arbustos hembra no estuvo asociado al régimen de ramoneo del año anterior $(39 \%$ y $44 \%$ en arbustos protegidos y ramoneados, respectivamente) sino al volumen de copa de la hembra evaluada y al sexo y la distancia del arbusto más cercano. El ramoneo bovino afectó el desempeño reproductivo de arbustos de $A$. canescens principalmente inhibiendo de la floración.

Stresses such as severe winters, droughts, crowding (in transplant gardens), and heavy seed production in the previous growing season may trigger sex shifts toward maleness in sexually labile fourwing saltbush shrubs (McArthur 1977, McArthur et al.1978, 1992, McArthur and Freeman 1982). Since fourwing saltbush has been described as being fairly sensitive to defoliation (Trlica et al. 1977, Pieper and Donart 1978, Price et al. 1989), herbivory may be a significant source of stress to this shrub. It is not known, however, whether cattle browsing can trigger floral phenotype shifts toward maleness in this species.

Besides inducing sex phenotype shifts, herbivory could have other equally important effects on shrub fecundity either by suppressing flowering or reducing fruit fill (Hendrix 1988, Milton 1995). Nonflowering occurs frequently in dioecious species of the genus Atriplex, and is considerably more common in male and female genotypes of fourwing saltbush than in monecious genotypes (Freeman and McArthur 1984), however, the relation 
between nonflowering and cattle-browsing is largely ignored. Artificial defoliation is known to reduce seed set of fourwing saltbush (Trlica et al. 1977), and while utricle fill is generally low (40 to $60 \%$ [Springfield 1970]), the direct effects of cattle-browsing on viable utricle production are unknown.

We conducted an experiment to test hypotheses related to the impacts of cattlebrowsing on sex expression, suppression of flowering, and fruit fill (sensu Springfield 1970) of the subdioecious tetraploid shrub fourwing saltbush. We tested the hypotheses that: 1) cattle-browsing would produce sex shifts toward maleness in fourwing saltbush, and that release from browsing would promote shifts in the opposite direction; 2) increasing levels of cattle-browsing would promote higher frequency of nonflowering shrubs; and 3) increasing levels of browsing by cattle would promote lower utricle fill percentages.

\section{Materials and Methods}

\section{Experimental design and data collection}

Our study site was located on the USDA-ARS Central Plains Experimental Range (CPER), approximately $60 \mathrm{~km}$ northeast of Fort Collins, Colo. $\left(40^{\circ} 49^{\prime} \mathrm{N}\right.$ $\left.107^{\circ} 47^{\prime} \mathrm{W}\right)$ at $1,650 \mathrm{~m}$ elevation. We conducted our research on a floodplain area, close to Owl Creek. Major soil types of our study site were Remmit loamy sands and Edgar loams. Fourwing saltbush, blue grama (Bouteloua gracilis [H.B.K.] Lag. ex Griffiths) and western wheatgrass (Agropyron smithii Rydb.), are the dominant plant species at the site (Liang et al. 1989). Mean annual precipitation is 320 $\mathrm{mm}, 50$ to $80 \%$ of which occurs between April and September (Hart and Ashby 1998). Rainfall during and immediately before our experiments was above the historical average, particularly in 1997 (559 $\mathrm{mm})$. Late spring and summer rainfall (May-September) was also considerably higher in $1997(436 \mathrm{~mm})$ relative to 1996 (294 $\mathrm{mm})$ and 1998 (275 mm).

We measured sex change, percent flowering and utricle fill on fourwing saltbush shrubs in $14,0.5$ ha experimental grazing pastures. The pastures were built in the fall of 1996 in 2 parallel blocks of 7 adjacent units each, within a pasture that had been moderately browsed by cattle in winter for approximately 20 years. At the beginning of the experiment, pastures within a block were assigned randomly to each treatment ( 3 seasons x 2 stocking densities + ungrazed control). Randomization was performed within each block of experimental pastures, subject to the constraint that no 2 adjacent pastures were grazed on the same date. Four different pastures were browsed with cattle for periods of 4 days in winter (January), early spring (April), and late summer (September) in 1997 and 1998. At each season, 2 pastures were browsed moderately with 4 heifers (weighing 400 to 520 $\mathrm{kg}$ ) and 2 were browsed heavily with 12 heifers. Moderate stocking densities (32 heifer days $\mathrm{ha}^{-1}$ ) simulated historical moderate grazing intensity used at the CPER (approximately 5.3 ha AUM-1 over a 6 month grazing season, 34 AU days ha-1). Heavy stocking rates were set at 3 times (96 heifer days ha ${ }^{-1}$ ) the moderate rates to ensure levels of defoliation likely to promote shrub fecundity alterations (Buwai and Trlica 1977, Trlica et al. 1977). Cattle used in the experiments were randomly assigned to the 0.5 -ha pastures and were always taken from herds grazing pastures with abundant fourwing saltbush, to minimize dietary and social adjustment.

Twenty female and 20 male shrubs were randomly selected and labeled in each 0.5 ha grazing pasture prior to the grazing treatment. In the second year (1998), we marked 20 randomly selected monecious shrubs as well. We were prevented from identifying monecious shrubs in the first season (1997) because inflorescences were badly damaged by a hail storm that occurred while we were in the process of marking shrubs in 1996. Shrubs with pistillate flowers were classified as females, those with staminate flowers were classified as males, and those with close-toequal proportions of pistillate and staminate flowers were considered monecious. Occasionally, at the end of the flowering phase, we found solitary utricles on shrubs that had been classified as males. These were possibly shrubs that had flowered as males, yet carried sexually labile genotypes. The identification of shrub genotype, however, went beyond the scope of this study so our classification was qualitative and made exclusively on the basis of the observed phenotype. On each shrub we measured utilization of marked leaders by cattle, greatest crown diameter, crown diameter perpendicular to the greatest diameter, crown height, and distance to closest shrub. In the late fall of 1997 , we collected utricles from 3 randomly selected female shrubs in each of the 14 grazing pastures. On each of the 42 female shrubs we measured crown dimensions (as described above), distance to closest and second closest shrub, and sexual phenotype of the closest shrub. We examined 100 utricles per plant to estimate the percentage of utricles containing embryos (utricle fill).

Utilization was determined by measuring differences in lengths (immediately before and after each 4-day browsing event) on 4 marked primary leaders on each labeled shrub. Base diameters and lengths of eaten secondary stems remaining on portions of utilized marked leaders were also measured. On female shrubs we marked both reproductive (with utricles) and non-reproductive leaders. Prior to each browsing event we harvested primary and secondary leaders from non-labeled female, male, and monecious (in 1998) shrubs in the experimental pastures. Each primary leader was labeled and sectioned into $6 \mathrm{~cm}$ long segments (approx) that were numbered sequentially from tip to base and placed in separate containers. Sectioned primary leaders were ovendried separately at $60^{\circ} \mathrm{C}$ for 48 to 72 hours. Secondary stems were also labeled, placed in separate containers, and ovendried in the same manner as were primary stems. We then recorded weights and lengths of the oven-dried segments from each primary stem, and base diameter, weight and length of each oven-dried secondary stem. Mean length-weight distributions of stems were used to construct a length-weight curve that was used to transform percent length measurements obtained in the field into percent biomass utilization estimates. A regression equation, relating total length of pooled male, female, and monecious primary leaders (predictor) to their total biomass (response), was also developed to calculate biomass of marked primary stems when necessary. Secondary stem measurements were also pooled and used to develop 2 regression equations: one relating base diameter (predictor) to stem length (response), and another relating stem length (predictor) to stem biomass (response). The first equation was used to estimate original length of eaten secondary stems. The second was used to estimate biomass of the length removed from utilized secondary stems. Length removed from a particular browsed secondary stem was calculated by subtracting the residual 
length measured in the field from the total estimated length (calculated using secondary stem base diameters measured with a dial caliper). Finally, total biomass removed from browsed secondary stems on a given marked primary leader was expressed as a percentage of its total estimated biomass. Thus, we obtained an overall estimate of utilization for each marked leader expressed in terms of percent biomass removed by cattle.

\section{Sex change}

We studied sex change in fourwing saltbush at the level of: a) experimental pastures; and b) individual marked shrubs. To evaluate sex change at the pasture level we set up 2 parallel transects in June of 1997 and 1998 in each grazing plot and determined sexual phenotype of the closest shrub to each $3-\mathrm{m}$ interval point along the transect. If the closest shrub at a given interval point was either a young shrub or a nonflowering adult, the second closest shrub was selected. The transects were not permanent, but were set up in the same general area in both years. Shrubs were classified as either females, males, or monecious. We examined a total of 100 shrubs per grazing plot each year, and obtained sex ratio estimates for each of the 14 grazing plots in 1997 and 1998. Sex change at the level of grazing plots was analyzed using contingency tables, to determine whether sex ratios were significantly related to grazing treatments. The significance of the factors included in the experimental design (block, season, and stocking density) was assessed in a preliminary analysis using a 4-way contingency table. Since effects of none of the factors were significant, the data were pooled into 2 classes (grazed and ungrazed) and collapsed into 2-way contingency tables. A separate table was constructed for 1997 and 1998, and then both of these were related using the CochranMantel-Haenszel test of general association (Ott 1993). Sex ratios for grazed and ungrazed classes (in 1997 and 1998) were also compared to the 35 male:55 female: 10 monecious tetraploid fourwing saltbush sex ratio described by McArthur (1977). Data were analyzed using PROCS CATMOD and FREQ of SAS version 6.12 (1996) package. Statgraphics Plus (1994) was used to perform the $\chi^{2}$ goodness of fit tests.

At the individual plant level we utilized permanently marked plants in each pasture. The previous season's floral phenotype of marked shrubs was compared to the floral phenotype of the current season. If a shrub exhibited flowers it was placed into 1 of 3 categories on the basis of its current season's floral phenotype, namely: a) changing toward maleness; b) changing toward femaleness; and c) constant sexual phenotype expression. Nonflowering shrubs were not included in this analysis. Once floral phenotype of marked shrubs was determined in June 1997, nonflower- ing and labile shrubs were replaced by newly marked shrubs to maintain a balanced number of flowering individuals ( $\mathrm{n}$ $=20$ ) in each sex phenotype class. Sex change at the individual shrub level was analyzed following 2 approaches. First, we analyzed counts of shrubs exhibiting either constant or labile (changing toward femaleness or maleness) sex expression in relation to browsing regime, to determine whether sex change and grazing treatments were significantly associated. Again, we used contingency tables and followed the same path of analysis described above for sex ratios. While the 1997 analysis included only shrubs that had been male or female in the previous year, in 1998 we analyzed counts from previously male, female and monecious individuals. The second analysis approach consisted of conducting discriminant analysis with data collected in 1998 to identify the variables that weighed most heavily on changes in shrub floral phenotype. Shrubs were grouped a priori into 2 categories: 1) those exhibiting shifts in sexual phenotype; and 2) those exhibiting sex phenotype constancy. Crown volume (CV), crown height:width ratio (HWR), distance to closest shrub (D1), percent utilization by cattle (U), length of rest between browsing event and onset of flowering in June (R), and sexual phenotype $(\mathrm{S})$ were the variables used to construct the discriminant function. This set

Table 1. Sex ratios and sex phenotype shifts in fourwing saltbush shrubs in relation to cattle grazing.

\begin{tabular}{|c|c|c|c|c|c|c|c|}
\hline \multirow[b]{2}{*}{ Year } & \multirow[b]{2}{*}{ Treatment } & \multicolumn{3}{|c|}{ Sexual phenotype } & \multirow{2}{*}{$\begin{array}{l}\text { Cochran-Mantel- } \\
\text { Haenszel }\end{array}$} & \multirow[b]{2}{*}{$\chi^{2}$} & \multirow[b]{2}{*}{$\mathrm{p}$} \\
\hline & & Male & Female & Monecious & & & \\
\hline & & $\ldots$ & $(\%)-$ & --------------- & & & \\
\hline \multirow[t]{2}{*}{1997} & Grazed & 41 & 45 & 14 & & & \\
\hline & Ungrazed & 36 & 54 & 11 & & 5.3 & 0.07 \\
\hline \multirow[t]{2}{*}{1998} & Grazed & 41 & 45 & 1 & & & \\
\hline & Ungrazed & 37 & 49 & 14 & & 1.1 & 0.30 \\
\hline Overall & & & & & 5.3 & & 0.07 \\
\hline
\end{tabular}

b) Sex phenotype shifts

\begin{tabular}{|c|c|c|c|c|c|c|c|}
\hline \multirow[b]{2}{*}{ Year } & \multirow[b]{2}{*}{ Treatment } & \multicolumn{3}{|c|}{ Phenotypic shift } & \multirow{2}{*}{$\begin{array}{c}\text { Cochran-Mantel- } \\
\text { Haenszel }\end{array}$} & \multirow[b]{2}{*}{$\chi^{2}$} & \multirow[b]{2}{*}{$\mathrm{p}$} \\
\hline & & $\begin{array}{c}\text { Toward } \\
\text { femaleness }\end{array}$ & $\begin{array}{l}\text { Toward } \\
\text { maleness }\end{array}$ & Constant & & & \\
\hline \multicolumn{8}{|c|}{ 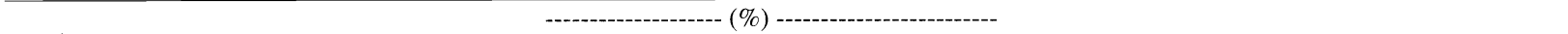 } \\
\hline $1997^{1}$ & Grazed & 1 & 9 & 90 & & & \\
\hline$\left(\left[\sigma^{x} \circ\right]\right.$ excluded $)$ & Ungrazed & 1 & 13 & 86 & & 0.80 & 0.670 \\
\hline 1998 & Grazed & 1 & 30 & 69 & & & \\
\hline ([ [ $\left[\begin{array}{ll}0^{x} & 9\end{array}\right]$ included) & Ungrazed & 13 & 20 & 67 & & 60.93 & 0.001 \\
\hline Overall & & & & & 48.43 & & 0.001 \\
\hline
\end{tabular}

In 1997 monecious shrubs ([ $\sigma^{\circ}$ o ]) were not included in the analysis. 
of variables was chosen to assess the relative impacts of shrub size (CV), shrub age (HWR), shrub density (D1), cattle-browsing $(\mathrm{U}, \mathrm{R})$, and floral phenotype $(\mathrm{S})$ on sex-change. The HWR of woody plants tends to decrease over the lifetime of an individual (Horn 1971) and was used as the best surrogate for shrub age. Length of rest period was expressed as a proportion of a year (days of rest/365). We constructed 2 discriminant functions, one for shrubs capable of shifting toward maleness and another for shrubs capable of shifting toward femaleness. The first function was developed using a subset of the data including flowering females and monecious shrubs that exhibited either constancy or a shift toward male floral phenotype. The second function was developed using a subset of data including flowering male shrubs, and monecious shrubs that exhibited either constancy or a shift toward female floral phenotype. Wilk's Lambda was used to test for significant differences between groups. Level of significance for all tests was set at $\mathrm{P} \leq 0.05$. We used PROCS CATMOD, FREQ, and DISCRIM of the SAS version 6.12 (1996) package to perform the statistical analyses.

\section{Nonflowering}

Nonflowering was studied at the individual plant level only. Counts of labeled nonflowering shrubs were analyzed following the same 2 approaches used for the analysis of sex-change at the individual plant level. Contingency tables were used to determine whether nonflowering was significantly related to grazing regime and to floral phenotype (male or female). Discriminant analysis was used to determine the variables weighing most heavily on shrub nonflowering. Contingency tables and discriminant functions were constructed in the same way as in the sexchange analysis, except that in this case contingency tables included only male and female shrubs. For the discriminant analysis, data were separated a priori into 2 groups: a) flowering shrubs; and b) nonflowering shrubs. Wilk's Lambda was used to test for significant differences between groups in the discriminant analysis. Level of significance for all tests was set at $\mathrm{P} \leq 0.05$. We used PROCS CATMOD, FREQ, and DISCRIM, of the SAS version 6.12 package (1996) to perform the statistical analyses.

Table 2. Discriminant analysis for fourwing saltbush shrubs on the basis of sex phenotype lability.

\begin{tabular}{lcc}
\hline \hline a) Discriminant scores & & \\
Shrubs capable of shifting & Constant & Labile \\
\hline Toward maleness & $4.3 \mathrm{a}^{1}$ & $3.5 \mathrm{~b}$ \\
Toward femaleness & $1.9 \mathrm{a}$ & $0.1 \mathrm{~b}$
\end{tabular}

b) Discriminant coefficients

\begin{tabular}{|c|c|c|}
\hline \multirow[t]{2}{*}{ 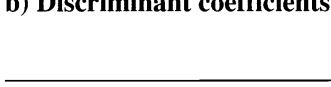 } & \multicolumn{2}{|c|}{ Shrubs capable of shifting } \\
\hline & Toward maleness & Toward femaleness \\
\hline Crown volume & 0.03 & 0.59 \\
\hline Distance to closest shrub & 0.21 & -0.30 \\
\hline Crown height : width ratio & 0.11 & 0.05 \\
\hline Percent utilization by cattle & -0.02 & 0.28 \\
\hline Length of rest period & 0.16 & -0.79 \\
\hline Sexual phenotype & 1.40 & 2.03 \\
\hline \multicolumn{3}{|l|}{ c) Correct classification } \\
\hline \multirow[t]{2}{*}{ Shrubs capable of shifting } & Constant & Labile \\
\hline & ----- & --------------- \\
\hline Toward maleness & 77 & 80 \\
\hline Toward femaleness & 83 & 95 \\
\hline
\end{tabular}

Different letters indicate significant differences at $\mathrm{P}=0.05$ between constant and labile groups in shrubs shifting toward maleness and shrubs shifting toward femaleness.

\section{Utricle fill}

Utricle fill was also analyzed at the individual plant level only. We conducted multiple regression analysis to determine which variables were significant predictors of fruit-fill at our experiment site. The predictors included in the model were: a) log crown volume (LCV); b) length of rest period between browsing event and onset of flowering in June (R); c) distance to closest shrub (D1); d) distance to second closest shrub (D2); e) sexual phenotype of closest shrub (dummy variables expressed by $S 1=1$ if male, else 0 , and $S 2=1$ if female, else 0 ). In addition to these, we also included 2 interactions of interest, namely: $\mathrm{D} 1 * \mathrm{~S} 1$, and $\mathrm{LCV} * \mathrm{~S} 1$. Crown volume was log- transformed in order to meet regression assumptions. Level of significance was set at $\mathrm{P} \leq 0.05$. We used PROC GLM of the SAS version 6.12 (1996) package to perform the statistical analyses.

\section{Results}

Mean shrub utilization in moderately grazed pastures was $35 \%$ in January, $15 \%$ in April, and $17 \%$ in September. In heavily grazed pastures, mean utilization was $54 \%$ in January, 25\% in April, and 50\% in September.

\section{Sex change \\ Pasture level}

Shrub sex ratios exhibited little annual variation in ungrazed exclosures or grazed pastures. Shrub sex-change and cattle- browsing were only marginally related at the level of experimental grazing plots (Table 1.a). Neither grazed nor ungrazed shrub sex ratios differed significantly $(\mathrm{P} \leq$ 0.05 ) from the 35 male: 55 female: 10 monecious frequency described for tetraploid fourwing saltbush (McArthur 1977).

\section{Individual shrubs}

Sex change on individual shrubs was not significantly associated with browsing in 1997 when monecious shrubs were excluded from the analysis (Table 1b). However, when monecious shrubs were included in 1998, the association was highly significant (Table 1b). Whereas sex shifts towards maleness were more frequent, only change toward femaleness was significantly associated with presence or absence of browsing; the shift toward femaleness occurred much more frequently $(\mathrm{P}=0.001)$ in exclosures than in the grazed plots (13\% vs $1 \%$; Table $1 b$ ).

Shrubs discriminated into the a priori defined classes on the basis of sexual phenotype constancy produced groupings that were significantly different from each other (Table 2a). Mean discriminant scores for shrubs exhibiting shifts in sexual phenotype were significantly lower (both in shrubs shifting toward maleness and femaleness) than mean scores of shrubs exhibiting constancy. Sex phenotype was the variable that weighed most heavily on both discriminant functions (Table 2b). Monecious shrubs tended to have smaller discriminant scores and were more likely to be placed in the sex-changing group. Distance to closest shrub, per- 
Table 3. Effect of distance to closest shrub, length of rest period, and percent utilization on the classification of labile female, labile male, and monecious fourwing saltbush shrubs.

\begin{tabular}{|c|c|c|c|c|}
\hline Variable & Magnitude & Labile female & Labile male & Monecious \\
\hline \multirow[t]{2}{*}{ Distance to closest shrub } & Large & constant & $\rightarrow q^{1}$ & $\rightarrow$ 운 \\
\hline & Small & $\rightarrow \sigma^{2}$ & constant & $\rightarrow \sigma^{x}$ \\
\hline \multirow[t]{2}{*}{ Length of rest period } & Long & constant & $\rightarrow$ q & $\rightarrow q$ \\
\hline & Short & $\rightarrow \sigma^{x}$ & constant & $\rightarrow \sigma^{x}$ \\
\hline \multirow[t]{2}{*}{ Percent utilization by cattle } & High & $\rightarrow \sigma^{x}$ & constant & $\rightarrow \sigma^{x}$ \\
\hline & Low & constant & $\rightarrow$ ㅇ & $\rightarrow q$ \\
\hline
\end{tabular}

${ }^{1}$ Shifts toward femaleness.

${ }^{2}$ Shifts toward maleness.

cent utilization by cattle, and length of rest period exhibited opposite signs in the discriminant functions corresponding to shrubs capable of shifting toward maleness and those capable of shifting toward femaleness (Table 2b). The discriminant functions correctly classified $80 \%$ of shrubs capable of shifting toward male-

Table 4. Percentages of fourwing saltbush that flowered or did not flower.

\begin{tabular}{llccccc}
\hline \hline Year & Treatment & Flowered & $\begin{array}{c}\text { Did not } \\
\text { flower }\end{array}$ & $\begin{array}{c}\text { Cochran-Mantel- } \\
\text { Haenszel }\end{array}$ & $\chi^{2}$ & $\mathrm{p}$ \\
\hline \multirow{2}{*}{1997} & Grazed & -92 & 18 & & & \\
& Ungrazed & 97 & 3 & & 5.0 & 0.03 \\
& & & & & & \\
1998 & Grazed & 65 & 35 & & 16.9 & 0.01 \\
& Ungrazed & 100 & 0 & & & 0.01 \\
\hline
\end{tabular}

ness and $95 \%$ of shrubs capable of shifting toward femaleness (Table 2c). Distance to closest shrub, percent utilization by cattle, and length of rest period had opposite effects on the sex phenotype status of labile females, labile males, and monecious shrubs (Table 3 ).

\section{Nonflowering}

Nonflowering and cattle-grazing were significantly associated (Table 4). Almost all labeled shrubs in exclosures (all of them in 1998) flowered, but up to approximately one third of labeled shrubs did not flower in browsed pastures (Table 4). Nonflowering was not significantly associated with shrub floral phenotype, it occurred as often among female shrubs as it did among male shrubs.

Shrubs discriminated into the classes defined a priori by the presence of flowers produced groupings that were significant- ly different from each other (Table 5a). Mean discriminant scores for flowering shrubs were significantly lower than mean scores of nonflowering ones. Percent utilization by cattle was the variable weighing most heavily upon the discriminant function (Table 5b). High levels of utilization produced high discriminant scores,

small discriminant scores and were, thus, classified as flowering; the opposite occurred with shrubs exhibiting small crowns. The discriminant functions correctly classified about $70 \%$ of both flowering and nonflowering shrubs (Table 5c). Overall, increasing levels of utilization by cattle and/or decreasing crown sizes were associated with increasing levels of nonflowering in fourwing saltbush at our site.

\section{Utricle fill}

Mean utricle fill of protected and grazed shrubs was similar. In both cases there was a large amount of among-shrub variation (Table 6). We found a significant relation between utricle fill and the overall set of variables included in our model $(\mathrm{df}$ $=39, \mathrm{~F}=2.41, \mathrm{P}=0.04, \mathrm{R}^{2}=0.38$ ). However, sexual phenotype of closest shrub, and the interactions both with distance to closest shrub and with log crown volume of the sampled female, were the only significant terms $(\mathrm{P}<0.05)$ in the multiple regression model (Table 6). Since the interaction terms were significant, we conducted separate regression analyses for shrubs with female or male neighbors. As distance to closest shrub increased, utricle fill decreased significantly if the closest shrub was a male $\left(\beta_{1}=-0.42 ; \mathrm{t}=-2.2 ; \mathrm{P}=\right.$ $0.02)$, and increased if the closest shrub was a female $\left(\beta_{1}=0.38 ; \mathrm{t}=2.30 ; \mathrm{P}=\right.$ $0.04)$. If the closest shrub was a male, utricle fill increased with increases in $\log$ crown volume $\left(\beta_{1}=66.9 ; \mathrm{t}=5.76 ; \mathrm{P}<\right.$ 0.01 ) but not if the closest shrub was a female $\left(\beta_{1}=-2.84 ; \mathrm{t}=-0.19 ; \mathrm{P}=0.85\right)$.

\section{Discussion}

causing an individual to be classified in the nonflowering group. The opposite occurred with individuals undergoing low levels of utilization. Crown volume was the second most influential variable. Shrubs with large crowns tended to obtain saltbush is genetically constrained (McArthur 1977, McArthur et al. 1992).

Table 5. Discriminant analysis for flowering and nonflowering fourwing saltbush shrubs.

\begin{tabular}{|c|c|}
\hline \multicolumn{2}{|l|}{ a) Discriminant scores } \\
\hline Flowering & Nonflowering \\
\hline $1.62 \mathrm{a}^{\mathrm{T}}$ & $1.93 \mathrm{~b}$ \\
\hline \multicolumn{2}{|l|}{ b) Discriminant coefficients } \\
\hline Crown volume & -0.38 \\
\hline Distance to closest shrub & 0.23 \\
\hline Crown height : width ratio & -0.30 \\
\hline Percent utilization by cattle & 0.90 \\
\hline Length of rest period & 0.13 \\
\hline \multirow{2}{*}{\multicolumn{2}{|c|}{ c) Correct classification }} \\
\hline & \\
\hline \multicolumn{2}{|c|}{ - } \\
\hline
\end{tabular}

${ }^{1}$ Different letters indicate significant differences at $\mathrm{P}=0.05$. 
Table 6. Utricle fill as affected by grazing

\begin{tabular}{lccc}
\hline \hline & & Utricle fill & \\
\cline { 2 - 4 } Grazing regime & Mean & SE & Range \\
\hline & -14 & \pm 2.6 & $15-78$ \\
Grazed & 49 & \pm 7.5 & $10-60$ \\
Ungrazed & & & $\mathrm{p}$ \\
\hline Multiple regression coefficients & Parameter estimate & $\mathrm{t}$ & 0.99 \\
& $<-0.01$ & -0.01 & 0.62 \\
Length of rest period (R) & 8.06 & 0.50 & 0.43 \\
Log crown volume (LCV) & 0.12 & 0.81 & 0.54 \\
Distance to closest shrub (D1) & -0.09 & -0.63 & \\
Distance to second closest shrub (D2) & & & 0.01 \\
Sexual phenotype of closest shrub (S 1) & 70.20 & 3.18 & \\
(if male $=1$, else $=0$ ) & & & 0.07 \\
Sexual phenotype of closest shrub (S 2) & 14.48 & 1.89 & 0.02 \\
(if female $=1$, else $=0$ ) & -0.41 & -2.44 & 0.03 \\
D1 $*$ S1 & 46.05 & 2.25 & \\
LCV $*$ S1 & & & \\
\hline
\end{tabular}

An estimated $55 \%$ of all shrubs carry sexually labile genotypes; the remaining $45 \%$ exhibit genotypic sex constancy. Within a season, approximately $2 / 3$ of shrubs with labile genotypes produce female flowers, $1 / 6$ produce male flowers, and the remaining 1/6 exhibit both male and female flowers (i.e. monecious shrubs). Shrubs with sex constant genotypes always flower as either males or females in close-to-equal proportions. Whereas overall phenotypic sex ratios are female biased with fairly constant proportions of female $(55 \%)$, male (35\%), and monecious (10\%) shrubs (McArthur 1977, McArthur and Freeman 1982, Barrow 1987, Petersen et al.1987, Cibils et al. 2000), sex shifting can trigger changes in phenotypic sex ratios of fourwing saltbush populations over time (Freeman and McArthur 1984). Shrubs with sexually labile genotypes are able to shift sex expression on a year-to-year basis as a response to environmental stress. Therefore, all 3 sex phenotypes are capable of sex shifting on a yearly basis, but such changes (given the phenotypic frequencies of labile genotypes mentioned above) are more frequent in shrubs that exhibit either monecious or female phenotypes (McArthur 1977, McArthur and Freeman 1982, Freeman and McArthur 1984).

Sex change in fourwing saltbush at our research site was significantly related to browsing at the level of individual shrubs. Exclosures exhibited a larger number of shrubs that shifted toward femaleness than did pastures that were browsed. Sex-shifts observed at the level of individual shrubs, however, did not translate into deviations of overall phenotypic sex ratios (as measured by the transect method we used) at the level of experimental pastures. The significant association between browsing regime and floral shifts was due primarily to the tendency of monecious shrubs (all of which carry labile genotypes) to change sexual phenotype (McArthur 1977, McArthur et al. 1992). The frequency of labile genotypes in our sample of marked shrubs, particularly in the $1997 / 98$ season, may have been higher than that of the population as a whole. This would account for the difference in response to browsingregime measured at the different levels at which we conducted the sex change study. In a plantation stand, McArthur and Freeman (1982) reported that $91 \%$ of monecious shrubs, $49 \%$ of females, and $15 \%$ of males changed sex over a 7-year period. Stress conditions (severe winters, droughts, crowding and heavy seed sets in the previous growing season) generally promoted changes toward maleness. Conversely, release from stress produced a return toward femaleness in labile shrubs (Gamarth 1972, McArthur and Freeman 1982). We observed a somewhat similar pattern at our site; small distance to closest shrub ( $\sim$ crowding ) was associated with shifts towards maleness and large distance to closest shrub was associated with changes toward femaleness.

Removal of leaves or flowers, or crown pruning have been reported to produce changes toward femaleness in sexually labile plants of at least 8 species (Freeman et al. 1980). Removal of storage organs, on the other hand, produced the opposite shift in at least 2 plant species (Freeman et al. 1980). Sex shifts toward maleness in fourwing saltbush at our site were weakly associated with very high utilization by cattle and short rest periods. Conversely, sex shifts toward femaleness were highly associated with low (or no) utilization by cattle and long rest periods. This trend is somewhat consistent with the reserve organ removal responses mentioned above, yet is opposite to sex shift trends reported in the defoliation and crown pruning examples. This apparent inconsistency may be explained by the fact that woody plants store reserve carbohydrates in perennial stems (Coyne et al. 1995), and that cattle browsing involves removal of leaves, fruits, and a considerable amount of stems (storage organs).

While shifts toward maleness were weakly associated with very high utilization by cattle (up to $53.6 \%$ in heavily grazed pastures) and short rest periods, they occurred in all the experimental pastures irrespective of browsing regime. Since our experiment was conducted in a shrub stand historically browsed by cattle in winter (when shrub utilization is highest [Shoop et al.1985]), it is likely that the level of stress imposed by our browsing treatments was not greater than the stress to which the shrubs were already subjected. Release from previous browsing stress, on the other hand, may have promoted a return toward femaleness in shrubs within exclosures. This would be consistent with the post-stress sex change reversal trends in fourwing saltbush reported by McArthur and Freeman (1982).

Shrubs with small crown volumes were more likely to be classified in the sexually labile groups, especially in the case of shrubs shifting sex expression toward femaleness. Changes toward femaleness were far more frequent in the exclosures. Reproductive output of small plants is affected more negatively by herbivory than is that of large plants (Marquis 1984). Therefore, it is not surprising that this variable weighed so heavily on the discriminant function for plants capable of shifting toward femaleness.

The association between cattle-browsing and nonflowering was highly significant. Nonflowering was much more frequent in browsed fourwing saltbush shrubs than in protected ones. Almost all shrubs in exclosures flowered in both years. Freeman and McArthur (1984) reported that occasionally (in 1 year of a 7-year study), nonflowering was slightly more common among female plants than among males. At our experimental site, nonflowering occurred as frequently in females as it did in males, both in 1997 and in 1998. Reduction in seed set is often reported as a direct consequence of herbivory or defoliation in 
plants (Edwards 1985, Elmqvist and Gardfjell 1988, Milton 1995), including fourwing saltbush (Trlica et al. 1977); but cases of nonflowering as a consequence of herbivory are uncommonly reported. Our results suggest that this more severe response may occur in fourwing saltbush grazed by cattle.

In annual agricultural crops, reduction in seed (fruit) production is proportional to amount of biomass removed by herbivores (Hendrix 1988). The relation between herbivory and fruit set in perennial plants is not as clear cut and is, in many instances, associated both with intensity and timing of herbivory events ( Hendrix 1988, and references therein, Milton 1995). Length and number of fruit-bearing stems in female fourwing saltbush shrubs can be reduced by defoliation (Buwai and Trlica 1977, Trlica et al.1977). Number and total weight of utricles increases exponentially with increasing crown volume (Stapp, unpublished data). Hence, cattle herbivory can be expected to cause overall reductions in fruit set, both directly, by reducing length and number of fruit stalks, and indirectly, by reducing crown size. Variation in fruit fill, however, was not significantly related to cattle browsing regime in our experiment. Crown volume was a significant predictor of fruit fill only when floral phenotype of the closest shrub was taken into account. The relatively wide range of percent utricle fill values we observed is consistent with previous reports (Springfield 1970, Gerard 1978). Springfield (1970) speculated that the large fruit fill variability among the fourwing saltbush shrubs he sampled could be governed by either genetic or site specific factors. Gerard (1978), who also observed a considerable degree of utricle fill variation among fourwing saltbush shrubs, reported no significant correlation between cumulative precipitation for various periods, or between total weight of fruit produced and percent utricle fill.

Sexual phenotype of the closest shrub and the interaction of floral phenotype of the closest shrub with both crown volume of the sampled female and distance to the closest shrub were the only significant explanatory variables of the set of predictors included in our model. Since fourwing saltbush is wind pollinated, it is likely that pollen flow dynamics may have been responsible for these interactions. If the closest shrub was a male (pollen source), fruit fill decreased with increasing distance to closest shrub. If, on the other hand, the closest shrub was a female (pollen flow interference factor), fruit fill increased with increasing distance to closest plant. Increases in crown volume were associated with increases in utricle fill when the closest shrub was a male. Larger crowns probably enabled sampled females to intercept larger amounts of pollen. If the closest shrub was a female, increases in crown volume were associated with closeto-zero changes in percent utricle fill.

Because pollen is thought to be rarely limiting in local populations of fourwing saltbush (McArthur et al. 1978) we did not expect these results. Strawbridge et al. (1997) reported that in plantations of river saltbush (Atriplex amnicola P.G. Wilson), optimum seed fills were obtained with a relatively wide range of shrub sex ratios (11 to $50 \%$ males). However, McArthur et al. (1978) found that, while pollen was abundant, the number of pollen grains captured down-wind from a solitary male shrub was 7 times larger than that captured at an equally distant spot in the opposite direction (44.2 vs 6.5 grains $/ \mathrm{mm}^{2}$ ). Spatial arrangement of male and female shrubs across the landscape interacting with crown volumes and the direction of predominant winds should, in turn, control the efficiency of pollen flow and indirectly affect utricle fill (Freeman et al. 1993).

\section{Conclusions}

Short-term cattle-browsing effects on shrub fecundity at our research site were mostly associated with increases in nonflowering. The magnitude of sex shifts (toward femaleness) associated with protection from browsing were not large enough to promote detectable alterations in shrub sex ratios. Consequently, previously observed differences in sex ratios between browsed stands and long-term exclosures (Cibils et al. 2000) could be a product of gender-specific shrub mortality rather than sex shifting. While release from the stress imposed by cattle-browsing was clearly associated with shifts toward femaleness in labile plants, the level of detail at which we addressed sexchange questions did not allow a quantification of this process. Our results, however, may merit further studies of a quantitative nature with greater control of environmental stress to assess the magnitude and importance of herbivory in promoting sex shifts in labile fourwing saltbush shrubs.

\section{Literature Cited}

Barrow, J.R. 1987. The effects of chromosome number on sex expression in Atriplex canescens. Bot. Gaz. 148:379-385.

Buwai, M. and M.J. Trlica. 1977. Multiple defoliation effects on herbage yield, vigor, and total nonstructural carbohydrates of five range species. J. Range Manage. 30:164-171.

Cibils, A.F., D.M. Swift, and R.H. Hart. 2000. Gender-related differences of shrubs in stands of Atriplex canescens with different histories of grazing by cattle. J. Arid Environ. 46:383-396.

Coyne, P.I., M.J. Trlica, and C.E. Owensby. 1995. Carbon and nitrogen dynamics in range plants. p. 59-127, In: D. J. Bedunah and R. E. Sosebee (ed), Wildland Plants: Physiological Ecology and Developmental Morphology. Soc. for Range Manage., Denver, Colo.

Crawley, M.J. 1997. Plant-herbivore dynamics. p. 401-474, In: M. J. Crawley (ed.), Plant Ecology, $2^{\text {nd }}$ Edition. Blackwell Sci., Oxford.

Edwards, J. 1985. Effects on herbivory by moose on flower and fruit production of Aralia nudicaulis. J. Eco. 73:861--868.

Elmqvist, T. and H. Gardfjell. 1988. Differences in response to defoliation between males and females of Silene dioica. Oecologia 77:225-230.

Freeman, D.C. and E.D. McArthur. 1984. The relative influences of mortality, nonflowering and sex change on the sex ratios of six Atriplex species. Bot. Gaz. 145:385-394.

Freeman, D.C., K.T. Harper, and E.L. Charnov. 1980. Sex change in plants: old and new observations and new hypotheses Oecologia 47:222-232.

Freeman, D.C., E.D. McArthur, S.C. Sanderson, and A.R. Tiedemann. 1993. The influence of topography on male and female fitness components of Atriplex canescens. Oecologia 93:538-547.

Gamarth, W.G. 1972. The relationship of plant morphology and seed processing to utricle fill and germination of fourwing saltbush (Atriplex canescens [Pursh] Nutt). M.S. Thesis. Montana State Univer., Bozeman, Mont

Gerard, J.B. 1978. Factors affecting fruit fill and seed germination of saltbus--405, In: D. N. Hyder. (ed.), Proc. $1^{\text {st }}$ Internat. Rangeland Congress. Soc. for Range Manage. Denver, Colo.

Hart, R.H. and M.M. Asby. 1998. Grazing intensities, vegetation, and heifer gains: 55 years on shortgrass. J. Range Manage. 51:392-398.

Hendrix, S.D. 1988. Herbivory and its impact on plant reproduction. p. 246-263, In: J. Lovett Doust and L. Lovett Doust (ed.), Plant Reproductive Ecology: Patterns and strategies. Oxford Univ. Press, New York, N.Y.

Horn, H.S. 1971. Speculations on the shapes of tree crowns. p. 104-117, In: H. S. Horn (ed.), The Adaptive Geometry of Trees. Princeton Univer. Press, Princeton, N.J. 
Liang, Y.M., D.L. Hazlett, and W.K. Lauenroth. 1989. Biomass dynamics and water use efficiencies of five plant communities in the shortgrass steppe. Oecologia 80:148-153.

Lowenberg, G.J. 1994. Effects of floral herbivory on maternal reproduction in Sanicula arctopoides (Apiaceae). Eco. 75:359-369.

Marquis, R.J. 1984. Leaf herbivores decrease fitness of a tropical plant. Sci. 226:537-539.

McArthur, E.D. 1977. Environmentally induced changes of sex expression in Atriplex canescens. Heredity 38:97-103.

McArthur, E.D. and D.C. Freeman. 1982 Sex expression in Atriplex canescens: Genetics and environment. Bot. Gaz. 143:476-482.

McArthur, E.D., D.C. Freeman, L.S. Luckinbil, S.C. Sanderson, and G.L. Noller.1992. Are trioecy and sexual lability in Atriplex canescens genetically based? Evidence from clonal studies. Evolution 46:1708-1721.

McArthur, E.D., A.P. Plummer, G.A. Van Epps, D.C. Freeman, and K.R. Jorgensen. 1978. Producing fourwing saltbush seed in seed orchards. p. 406-410, In: D. N Hyder.(ed.), Proc. $1^{\text {st }}$ Internat. Rangeland Congress. Soc. Range Manage. Denver, Colo.
Milton, S.J. 1995. Effects of rain, sheep and tephritid flies on seed production of two arid Karoo Shrubs in South Africa. J. App. Ecol. 32:137-144.

Ott, R.L. 1993. An introduction to statistical methods and data analysis, $4^{\text {th }}$ Ed. Duxbury Press, Belmont.

Paige, K.N. and T.G. Whitham. 1987. Overcompensation in response to mammalian herbivory: the advantage of being eaten. Amer. Natur. 129:407-416.

Petersen, J.L., D.N. Ueckert, R.L. Potter, and J.E. Huston. 1987. Ecotypic variation in selected fourwing saltbush populations in western Texas. J. Range Manage. 40:361-366.

Pieper, R.D. and G.B. Donart. 1978 Response of fourwing saltbush to periods of protection. J. Range Manage. 31:314-315.

Price, D.L., G.B. Donart, and M. Southward. 1989. Growth dynamics of fourwing saltbush as affected by different grazing management systems. J. Range Manage. 42:158-162.

Richards, A.J. 1997. Plant Breeding Systems, $2^{\text {nd }}$ Ed. Chapman and Hall, London.

SAS Institute. 1996. SAS/base and SAS/stat software. SAS Institute Inc. Cary, N.C.
Shoop, M.C., R.C. Clark, W.A. Laycock, and R.M. Hansen. 1985. Cattle diets on shortgrass ranges with different amounts of fourwing saltbush. J. Range Manage. $38: 443-449$.

Springfield, H.W. 1970. Germination and establishment of fourwing saltbush in the southwest. USDA-Forest Service Research Paper RM-55. Rocky Mountain Forest and Range Experiment Station, Fort Collins, Colo.

Statgraphics. 1994. Statgraphics Plus. Release 7.0 for DOS. Manugistics Inc. Rockville, $\mathrm{Md}$

Strawbridge M., R.W. Bell, J.A. McComb, E.G. Barrett-Lennard. 1997. Influence of sex ratio and sex lability on seed production in the dioecious perennial shrub Atriplex amnicola (Chenopodiaceae). Australian J. Exp. Agr. 37:661-666.

Trlica, J., M. Buwai, and J. Menke. 1977. Effects of rest following defoliations on the recovery of several range species. J. Range Manage. 30:21-27. 